\title{
A smarter way to combat hunger
}

\section{Traditional approaches to supplying food are an inefficient 'band aid', says Pedro A. Sanchez. New evidence shows that helping farmers to help themselves is more effective and would be six times cheaper.}

$\Lambda$ fter decades of progress in the fight to vanquish world hunger, the number of undernourished people is growing again. Estimates from the Food and Agriculture Organization of the United Nations suggest that 963 million people ${ }^{1}$ in poor countries are chronically or acutely hungry - up 109 million from 2004 estimates $^{2}$. The underlying causes - changes in food and energy prices $^{3}-$ have been exacerbated by the financial crisis and obsolete development policies.

Policies should shift from prioritizing food aid to providing poor farmers with access to training, markets and to farm inputs such as fertilizer and improved seed. In addition to being cheaper, such investments allow farmers to grow food to feed themselves, to sell the surplus and to diversify into high-value crops, livestock and tree products. This creates a sustainable exit from the poverty trap, thereby decreasing the requirement for aid. Although marginal populations, or those affected by disasters, will still require assistance, procuring this food from within developing countries provides a cheaper alternative than shipping it from abroad.

The predominant policies to tackle hunger epitomize a 'band-aid' approach - quick fixes that fail to address the causes of hunger. In 2006, the United States spent US $\$ 1.2$ billion in food aid for Africa, but only $\$ 60$ million on agricultural development there ${ }^{4}$. The international response has generally been similar. But according to estimates from 2004 , only $10 \%$ of those who are hungry in poor countries are acutely hungry - those facing famine caused by wars, natural disasters or sheer destitution. The other $90 \%$ are chronically hungry, leading to malnutrition that compromises immune systems and contributes to the prevalence of diarrhoea, malaria and other diseases that result in high child mortality ${ }^{2}$. Most of those who are chronically hungry live in rural farm households in Africa and South Asia.

Food aid fails to provide a sustainable solution to hunger and poverty and it is comparatively expensive. It costs $\$ 812$ to deliver one tonne of maize as US food aid to a distribution point in Africa ${ }^{5}$. As part of the Millennium Villages project, which I co-direct, smallholder farmers (those who farm $0.1-5$ hectares) in hunger hot spots across Africa were provided with access to fertilizers, improved seed, technical support and markets. As a result, maize yields more than doubled - from 1.7 to 4.1 tonnes per hectare ${ }^{6}$. And following a national 'smart' subsidy programme for fertilizer and hybrid seed in Malawi, average maize yields increased from 0.8 to 2.0 tonnes per hectare in two years ${ }^{7}$.

The fertilizer and improved seed required to produce an additional tonne of maize grain by Millennium Village farmers cost an average of $\$ 135$ at April 2008 prices $^{6}$, six times less than through food aid. Purchasing that same tonne of maize locally - in an African country or a

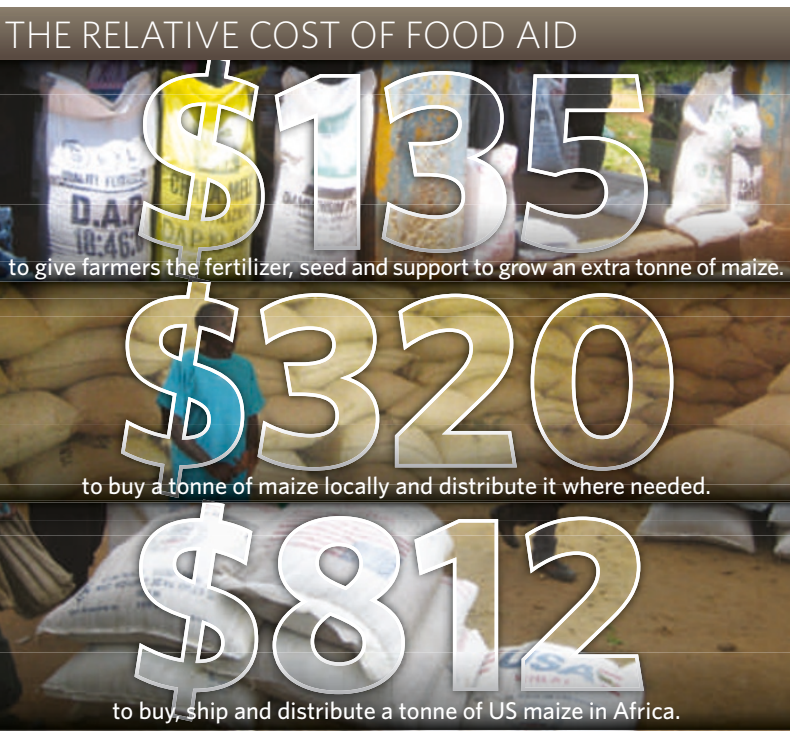

neighbouring one - costs approximately $\$ 320$ (ref. 5). If farmers in Africa raise their average cereal yields to 3 tonnes per hectare, the additional 200 million tonnes grown in the 100 million hectares of smallholder crop land will more than compensate for the 3.2 million tonnes of food aid ${ }^{8}$.

Although estimates of efficiency vary, they indicate a major leap for development assistance. Shifting $50 \%$ of the current US food-aid budget to 'smart' subsidies or credit could help millions supply their own food and meet much of the aid demand. Such a move would be budget neutral.

Even buying food locally represents an important step away from the inefficient foodaid approach. Some institutions have already begun to change their methods. In 2007, CARE International, a leading relief organization headquartered in Atlanta, Georgia, announced that it would stop monetizing food aid (selling some of the food to fund their operations), essentially losing $\$ 46$ million a year. Also in 2007 , the World Food Programme procured $43 \%$ of the 2 million tonnes of food required for its Africa relief operations from farmers in Africa at an average cost of $\$ 280$ per tonne - compared with the average cost of $\$ 436$ for purchases elsewhere? ${ }^{9}$. The new Purchase for Progress programme, launched in September 2008 and funded by the Bill \& Melinda Gates Foundation further empowers the World Food Programme to purchase food from African farmers.

Most importantly, the UN secretary general Ban Ki-moon is leading the development of a coordination mechanism for large-scale financial support for poor countries seeking to provide farm investment. The Spanish government has pledged $€ 1$ billion (US $\$ 1.3$ billion) over five years for this effort, which should begin this year, and the European parliament has promised a similar amount. With more programmes aimed at merging food aid with reliable farming investment, the numbers of those who are chronically hungry should begin to fall.

Pedro A. Sanchez is senior research scholar and director of tropical agriculture at the Earth Institute at Columbia University, 61 Route 9W, Palisades, New York 10964, USA. e-mail: psanchez@ei.columbia.edu

Diouf, J. Speech at High-Level Meeting on Food Security for All Madrid, 26-27 January 2009. Available at www.ransa2009. org/docs/docs/speech_DG_FAO_ransa2009.doc.pdf

2. Sanchez, P. A. \& Swaminathan, M. S. Science 307, 357-359 (2005).

3. von Braun, J. Nature 456,701 (2008).

4. The Chicago Initiative on Global Agricultural Development Renewing American Leadership in the Fight Against Global Hunger and Poverty (Chicago Council on Global Affairs, 2009). Available at http://www.thechicagocouncil.org/ globalagdevelopment/pdf/gadp_final_report.pdf

5. Garrett, L. A. Food Failures and Futures Maurice R. Greenberg Center for Geoeconomic Studies Working Paper (Council on Foreign Relations, 2008).

6. Sanchez, P. A., Denning, G. L. \& Nziguheba, G. Food Security 1, 37-44 (2009).

7. Denning, G. et al. PLoS Biol. 7, e1000023 (2009).

8. http://one.wfp.org/interfais/2008/tables/Table10.pdf

9. Jury, A. New Roles for Food Assistance: How Can Food Aid Support Agricultural Growth and Productive Safety Nets in Africa? Presentation at the World Food Prize Symp., 22 October 2008 (World Food Programme, 2008).

Join the debate at http://tinyurl.com/cy3xc6. 